\section{Lembaran} Sejarah

\title{
Policy of Kampong Improvement and Public Housing: Surabaya Colonial Period (1900-1940)
}

\section{IDAM SETIYAWAN}

Universitas Gadjah Mada

\begin{abstract}
The origins of the policy of kampong improvement and public housing beginning of the 20th century and anyone who participated in it in encouraging the policy and its results originated from the poor condition of the kampong environment in the Surabaya city since the 1900s, which has caused the spread infectious diseases and casualties for the urban community and the lack of provision of adequate housing for them. Kampong and people's housing problems developed in 1925, along with the ethical political discourse of the Indies in the early 20th century. The characters such as Tillema, Thomas Karsten, Von Vaber, Westerveld and dr Soetomo began to participate. kampong situation and lack of public housing eventually became the attention of Surabaya city government. The improvement of indigenous kampong in Krembangan and other kampong. And the construction of public housing for the community people in Sidodadi and other areas has been done and has become one of the most interesting portraits in the policy of kampong improvement and public housing in Surabaya city.
\end{abstract}

\begin{abstract}
Abstrak
Asal usul kebijakan perbaikan kampung dan perumahan rakyat dimulai pada abad ke-20 dan siapa saja yang berpartisipasi di dalamnya dalam mendorong kebijakan tersebut dan hasilnya berasal dari kondisi lingkungan kampung yang buruk di kota Surabaya sejak 1900-an, yang menyebabkan menyebarnya penyakit menular dan korban jiwa bagi masyarakat perkotaan dan kurangnya penyediaan perumahan yang layak bagi mereka. Kampung dan masalah perumahan rakyat berkembang pada tahun 1925, bersamaan dengan wacana politik etis Hindia di awal abad ke-20. Tokoh seperti Tillema, Thomas Karsten, Von Vaber, Westerveld dan dr Soetomo mulai ikut serta. Situasi kampung dan kurangnya perumahan rakyat akhirnya menjadi perhatian pemerintah kota Surabaya. Perbaikan kampung adat di Krembangan dan kampung lainnya. Dan pembangunan perumahan rakyat untuk masyarakat di Sidodadi dan daerah lainnya telah dilakukan dan telah menjadi salah satu potret yang paling menarik dalam kebijakan perbaikan kampung dan perumahan rakyat di kota Surabaya.
\end{abstract}

\section{Keywords:} policy; participation; kampong; public housing; Surabaya

Kata kunci: kebijakan; partisipasi; kampung; perumahan rakyat; Surabaya 


\section{Development of Surabaya City and His Society}

At the beginning of the 20th century, Dutch policy experienced the most fundamental change in its history. Democracy seeks to be realized through the voices of popular councils even though the majority consists of westerners. ${ }^{1}$ Dutch colonial policy that was originally exploited was replaced with a statement of concern over the welfare of the Indonesian nation. This policy is called 'ethical politics' rooted in criticism in Max Havelar's novel (1860). This policy brought about a change in its view of the colonies. In 1901, Queen Wilhelmina (1890-1948) declared an inquiry into the welfare of the people of the Indies which was handed over to the Minister of Colonies, Alexander W.F. Idenburg, which was then followed by heads of regions in each city, ${ }^{2}$ as the decentralization law of 1903, and the formation of the city government (Batavia, Surabaya and Semarang), which was soon followed by other cities. So the city government is easier to manage the area independently in terms of infrastructure and city planning. ${ }^{3}$

On April 1, 1906 Surabaya was designated as Municipality (Gemeente) based on the regulations in the State Gazette (Staatsblad) no. $149 .{ }^{4} \mathrm{Mr}$. A. Meijroos was appointed as the first mayor of Surabaya City, in accordance with the decision of the Dutch East Indies Council dated August 3, 1916. ${ }^{5}$ Followed by G.J. Dijkerman (1920-1925), , H.I. Bussemaker (1925-1930), ${ }^{7}$ WH van Helsdingen (1930-1935) and W.A.H. Fuchter (1935-1942). ${ }^{8}$ In carrying out his work, the mayor is assisted by the Public Works Department (Wethouder Publike Werken), the Department of Electricity and Energy (Wethouder Bedrijven), and the Bumiputera Affairs Department. As well as the unity of city police, city council, and some advisers from European, Chinese and Native representatives.

The city of Surabaya developed into a modern city that is quite crowded. This can not be separated from the role of industrial development and transportation. The new harbor at Tanjung Perak was built in 1910 to replace the old port of Kalimas to facilitate the loading and unloading activities of

1) Sartono Kartodirdjo. 1993. Pengantar Sejarah Indonesia Baru: Sejarah Pergerakan Nasional, dari Kolonialisme sampai Nasionalisme, Jilid 2 (Jakarta: PT Gramedia), pp. 44.

2) M.C. Ricklefs. 2007. Sejarah Indonesia Modern 1200 - 2004, (Jakarta: PT. Serambi Ilmu Semesta), pp. 319-321.

3) Peter J.M. Nas dan Martien De Vletter. 2009. Masa Lalu dalam Masa Kini: Arsitektur Indonesia (Jakarta: PT. Gramedia Pustaka Utama), pp.132-134.

4) Verslag der Gemeente Soerabaja over 1918 (Soerabaja: J.M.C.H.S Nijland, 1920), pp. 1.

5) Arnhemsche Courant, August 04, 1916.

6) Provinciale Geldersche en Nijmeegsche Courant, October 28, 1920.

7) Limburgsch Dagblad, March 01, 1929.

8) Andjarwati Noordjanah. 2004. Komunitas Tionghoa di Surabaya (1900-1946) (Semarang: Masyarakat Indonesia Sadar Sejarah), pp. 13. 
imported and exported goods that are constantly increasing. ${ }^{9}$ As well as the construction of Surabaya-Pasuruan and Surabaya-Batavia railway lines in 1912 to facilitate the mobilization of Surabaya city residents from or out of town. ${ }^{10}$

The development of facilities and infrastructure is growing. Many magnificent buildings in every major street of Surabaya. For example along the Darmo Boulevard Highway stands a luxury housing estate and large buildings that are famous as the main street of the city, which has an area of 230 hectares. ${ }^{11}$ So also in the area of Keputran, built elite housing in 1905 by Bouwmaatschapij Keputran with the system of rent or purchase. As well as in the Ketabang, Ambengan and Gubeng areas, the city government has also built pilot houses for upper middle class civil servants in $1917 .{ }^{12}$ The city of Surabaya was created for the Dutch East Indies in particular, so many other typical colonial buildings in Middle of the city, used as a place of recreation, school, elite settlement, military headquarters. The development of course has an impact on the situation of kampong in the city of Surabaya is increasingly compacted and pressed. So that once caused social unrest in 17 kampong in $1915 .^{13}$

The growth of population in Surabaya always increases. The city of Surabaya has a population of about 150,000 in 1905. The number began to increase rapidly around 336,817 people in 1930 . This is related to the development of trading industry in the city of Surabaya. ${ }^{14}$ So encouraging the arrival of people from outside the city of Surabaya to work in urban areas as port transport workers or factory workers.

Since 1826, the Dutch East Indies Government passed the Wijkenstelsel law. ${ }^{15}$ So the location of the population in Surabaya is divided based on ethnicity. European community settlements are located around the Red Bridge, Simpang and Darmo. On average they work in government structures and big businessmen. Chinese settlement is in Kembang Jepun area, Kapasan, Atomic Market (Chinese camp), mostly work as a merchant providing the needs of urban community. Furthermore, the settlement of Arabs resides

9) Nasution. 2006. Ekonomi Surabaya pada Masa Kolonial 1830-1930(Surabaya: Intelektual), pp. 77-80 dan Pieter Creutzberg and J.T.M. van Laanen. 1987. Sejarah Statistik Ekonomi Indonesia (Jakarta: Yayasan Obor Indonesia), pp. 139-141.

10) Handinoto. 2010. Arsitektur dan Kota-kota di Jawa pada Masa Kolonial (Yogyakarta: Graha Ilmu), pp. 329.

11) Dukut Imam Widodo. 2004. Soerabaia Tempo Doeloe. Buku 2 (Surabaya: Dinas Pariwisata dan Kebudayaan Surabaya), pp. 322.

12) Freek Colombijn, dkk. 2015. Kota Lama, Kota Baru: Sejarah Kota-Kota di Indonesia Sebelum dan Setelah Kemerdekaan (Yogyakarta: Ombak), pp. 440.

13) Barlan Setiadijaya. 1992. 10 November 1945 Gelora Kepahlawan Indonesia (Jakarta: Yayasan 10 November 1945), pp. 43.

14) Sri Margana dan M. Nursam. 2010. Kota-Kota di Jawa: Identitas, Gaya Hidup dan Permasalahan Sosial (Yogyakarta: Ombak), pp. 192.

15) Handinoto, op.cit., pp. 358. 
in the area around the Ampel mosque (Arabic camp) which has many gang kampongs like Ampel Gading kampong, Ampel Suci and in Nyamplungan kampong area. ${ }^{16}$ They also work as traders. While the indigenous settlements are located in kampong located close to the three settlements above, ${ }^{17}$ and life is very simple, adhering to a thrifty lifestyle and satisfied with living in a slum. ${ }^{18}$ On average they work as laborers or housemaids and other informal sectors.

\section{Discourse and Physical Condition of Indigenous Kampong Colonial Period}

High population and urbanization in Surabaya is a consequence of city development. This resulted in high demand for housing. The Europeans, Chinese, Arabs, and Natives all need a place to live and a place of business. This means that if the number of housing needs is not comparable with the provision of housing by the city government of Surabaya, it will cause social problems in the field of social and health. One of them is the emergence of slums in a kampong that is considered to have caused various infectious diseases and contagious since the beginning of the 20th century.

The kampong title is meant for a limited settlement environment with a group of homes, which are usually inhabited by low-income people and a unity in business and ethnicity. Indigenous kampong are rarely seen prominently in a city, because they do not take strategic positions such as Chinatown, elite or important buildings that are the point of orientation for all passers-by. ${ }^{19}$

Indigenous kampong are usually built around the river. Their lives are identical to rivers where river water is usually used for bathing and drinking, as well as toilets and garbage discharges associated with other rivers to become contaminated and cause disease. ${ }^{20}$ Described the calamity epidemic spread in Surabaya occurred in 1875, 1883 until 1896, 1900 and 1902. Hospitals have been established since 1808 in the Simpang area, but specifically for Europeans and military personnel only. Until 1905, the city government of Surabaya has not built a significant health facility for the community. ${ }^{21}$

It can be said that at the beginning of the 20th century, the condition of indigenous kampong environment was not as good as the settlement of the Dutch and Chinese people. A study illustrating the poor neighborhood

16) Freek Colombijn, op.cit., pp. 441.

17) Handinoto. 1996. Perkembangan Kota dan Arsitektur Kolonial Belanda di Surabaya (1870-1940) (Yogyakarta: Universitas Kristen Petra Surabaya dan Penerbit Andi), pp. 57.

18) Oliver Johannes Raap. 2013. Pekerdja di Djawa Tempo Doeloe (Yogyakarta: Galang Pustaka), pp. xvii.

19) Olivier Johannes Raap. 2015. Kota di Djawa Tempo Doeloe (Jakarta: Kepustakaan Populer Gramedia), pp. 139.

20) Adrian Vickers. 2005. Sejarah Indonesia Modern (Yogyakarta: Insan Madani), pp. 111.

21) Handinoto, op.cit., pp. 49. 
concentration of most low-income indigenous populations is made by D.J.A. Westerveld in 1914. ${ }^{22}$ Where disclosed, that the kampong is a very bad hut and not worth mentioning as human habitation. Most are wood or bamboo walls and grounded. ${ }^{23}$

The low attention of the Netherlands Indies government to indigenous settlements can also be known from Tillema's writings entitled "Kromablanda" written between 1915 and 1922. Tillema shows one of the conditions of indigenous population of Surabaya in Kampong Doro, which is bad and can lead to various diseases able to take casualties every year. ${ }^{24}$ Tillema writes urban conditions in urban areas as follows: “... many things need to be done in the city of Indonesia. Everything is really still to be repaired, such as public health services, kampong lighting, sanitation, structuring of densely populated areas, general housing improvements, soil drains, sewerage, food hygiene supervision, none of which are feasible ... ${ }^{25}$

So also according to Von Faber in his book "Nieuw Soerabaia". It is said that the houses of indigenous people in the city of Surabaya adjacent to an unhealthy animal cattle enclosure. Indigenous settlement houses tend to be narrow, irregular, tap water is also sometimes absent, let alone lighting electricity. ${ }^{26}$

Looking at the worsening health of the kampong, its rivers and gullies have been contaminated with human-caused liquid waste, which can threaten the health of urban residents of all ages and social classes. Then try to do health improvement program of society and its environment for indigenous society by some urban community leaders.

One of them is H.F. Tillema, and his friend H. Thomas Karsten. They introduced a call to perform a culture of "Healthy Ideology" in socializing lives in urban slums. They invite children who live in the kampong to follow health and hygiene counseling, which is assisted by the Surabaya City Government as a funder. In addition, Tillema also proposed, to build a new kampong that is more organized layout of the house and equipped with water channels, garbage disposal system, and the park because of the kampong conditions in the colonial period was too severe and impossible to repair. Meanwhile,

22) Johny A. Khusyairi dan La Ode Rabani. 2011. Kampung Perkotaan Indonesia: Kajian Historis-Antropologis atas Kesenjangan Sosial dan Ruang Kota (Yogyakarta: New Elmatera), pp. 16.

23) Amir Karamoy,1984. Program Perbaikan Kampung: Harapan dan Kenyataan (Majalah Prisma 6, XIII), pp. 24-38.

24) Tillema. 1915-1922. "Kromoblanda”: Over't Vraagstuk van 'het Wonen' in Kromo's Groote Land, deel. 1 (s-Gravenhage: Uden Masman (etc)), pp. 14-17.

25) Amir Karamoy, log.cit.

26) Von Faber, G.H. 1936. Nieuw Soerabaia: De Geschiedenis van Indie's Voornaamste Koopstad in de Eerste Kwarteeuw Sedert Hare Instelling 1906-1931 (Soerabaia: N.V. Boekhandel en Drukkerij), pp. 155-157. 
according to Thomas Karsten this proposal is quite good, but the problem of unrestricted kampong can be overcome only by improving the infrastructure, because the city is able to preserve his own kampong in the future. ${ }^{27}$

Tillema also quotes De Vogel's speech of September 15, 1915 in Colonial Instituut, about the number of people dying of infectious diseases in the Indies, especially in Java. So Tillema suggested that the government pay attention to the health of the indigenous people and make improvements to the settlement because it has a lot of writing about it. As A. van Balen wrote about the poor water and sanitation policy of the Indies era under the title "A Survey of The Drinking Water and Sanitation: Policy In The Dutch East Indies 1872-1942". Similarly, research on health related to urban community building conditions conducted by G.W.F. Vos in his book, "Indissche Bouwhiggiene, Proeve van Eengtalpassing van De Gezondheidesleer Bij Het Bouwen in Nederlands Indie”. However, the results of this research are still stored in government office cabinets without regard to them. ${ }^{28}$

In addition to the Europeans, there is also another figure from the natives, namely Dr. Soetomo. In the 1920s Dr. Soetomo provided cheap or free treatment for those who were not able to financially for the kampong community who were mostly unhealthy in their environment, so that the living standard of poor people in Surabaya increased and could do their job activity again. So according to Dr. Soetomo, communication and association with the small people in any form it needs to be intensified. ${ }^{29}$ The Surabaya city government remains uninterested in improving slums and providing housing in various corners of the city.

In the 1920s, the Dutch colonial government paid attention to the unhealthy environment of the kampong community. ${ }^{30}$ According to the colonial government, healthy kampong life is important for the colonial government itself, in order for economic productivity to continue. So that the health of workers or factory workers who live in the kampong, as well as the community in general is well preserved through the program of kampong improvement and provision of public housing.

\section{Kampong Improvement and Public Housing Colonial Period in Surabaya}

Along with the unhealthy of kampong caused by the spread of infectious diseases that have caused casualties, between 1900-1931 in kampong Kapasan,

27) Sri Margana op.cit., pp. 74-75.

28) Djoko Soekiman. 2011. Kebudayaan Indis: Dari Zaman Kompeni sampai Revolusi (Jakarta: Komunitas Bambu), pp. 122.

29) William H Frederick. 1989. Pandangan dan Gejolak: Masyarakat Kota dan Lahirnya Revolusi Indonesia (Surabaya 1926-1946) (Jakarta: Gramedia), pp. 29-30.

30) Handinoto, op.cit., pp. 49. 
Krembangan, Kupang, Sukolilo and Kranggan. ${ }^{31}$ The city government of Surabaya to improvement the kampong by repairing the road around the house and gave him street lighting, and hardened the entrance gang kampong, ditch water and build water pump facilities, Bath or public toilet, as well as health treatment for the community. The city government has the right to kampong to build something. ${ }^{32}$ For example done J.H. De Haas, tried to pioneer the nutrition improvement program for infants for indigenous people and distributed powdered milk to mothers and introduced innovative soy milk production as an alternative source of vitamins. ${ }^{33}$

An article Soeloeh Indonesia, 1927, reported that the Surabaya city government held an opening for the construction of a clean water pump for the people of Surabaya to overcome the bad environment of the kampong that is prone to the spread of disease. The provision of clean water pumps is very beneficial for residents of Surabaya's urban kampong. So after that, started many established water pumps in other places. The opening ceremony was quite lively: "...Old people in Surabaya still remember the style in which the water policy was made. There are festive opening, speeches, light show, and with big banners: crystal clear tap water, and no cost...". ${ }^{34}$

In 1929, this kampong improvement program spread in 52 kampong, which contained about 17,188 houses. ${ }^{35}$ As for example that happened in kampong Sidodadi based on the central government's decision, obtaining a donation of $f 13,300$, to improve the water channel and kampong street. ${ }^{36}$ Surabaya City Government also made improvements in the kampongs of Krembangan, Kemayoran and Kapasan costing f $111,000 .{ }^{37}$ Simolawang and surrounding kampong also did not escape from this kampong improvement program, which cost $f 85,000 .{ }^{38}$ If this is not immediately done, then the decline of the kampong will affect the health of the European settlement environment in the future. ${ }^{39}$

31) De Indische Courant, April 25, 1928, De Indische Courant, November 23, 1927, De Indische Courant, February 26, 1926, Soerabaijasch Handelsblad, February 25, 1931.

32) Taufik Abdullah dan Sukri Abdurrachman (ed). 2011. Indonesia Across Orders: Arus Bawah Sejarah Bangsa (1930-1960) (Jakarta: LIPI Press), pp. 59-60.

33) Adrian Vickers, op.cit., pp. 36-37.

34) Rudolf Mrazek. 2006. Engineers of Happy Land: Perkembangan Teknologi dan Nasionalisme di Sebuah Koloni (Jakarta: Yayasan Obor Indonesia), pp. 82.

35) "Subsidieering van werken ter verbetering van toestanden in de kampongs, Gemeente Soerabaja”, Arsip Nasional Republik Indonesia, BB, no. 1696.

36) De Indische Courant, July 09, 1930.

37) De Indische Courant, July 24, 1937.

38) Soerabaijasch Handelsblad, July 12, 1939.

39) Abidin Kusno. 2012. Zaman Baru Generasi Modernis: Sebuah Catatan Arsitektur (Yogyakarta: Ombak), pp. 72. 


\begin{tabular}{|c|c|c|c|}
\hline Kampong Name & Wide Area & Character Improvement & Cost \\
\hline Sidodadi & $9 \mathrm{Ha}$ & All & f. 78.000 \\
\hline Srengganan Kertopaten & $10 \mathrm{Ha}$ & Some Area & f. 24.750 \\
\hline Simolawang Simokerto & $61 \mathrm{Ha}$ & Some Area & f. 198.000 \\
\hline Tambak gringsing & $57 \mathrm{Ha}$ & Some Area & f. 25.000 \\
\hline Maspati & $7 \mathrm{Ha}$ & Some Area & f. 6.000 \\
\hline Plampitan & $55 \mathrm{Ha}$ & All & f. 181.000 \\
\hline
\end{tabular}

Table 1.

The Result of Kampong Improvement by Surabaya City

Government in 1931. Source: Johan Silas. 1982. Program Perbaikan Kampung di Surabaya 1969-1982, Suatu Inventarisasi dan Evaluasi (Surabaya: Badan Pelaksana Pembangunan Program Perbaikan Kampung Pemerintah Kotamadya Daerah Tingkat II Surabaya dan ITS), pp. 10.

In addition to improving the kampong for the worsening urban environment, the city government also provides decent housing for its citizens. Initially, in 1914, the Surabaya City Government built a special indigenous peoples' public housing in a Gubeng railway company costing f 2,000 and subsidized maintenance of $\mathrm{f} 2,000$ divided equally to each train person. The funds were obtained from the Governor General of the Netherlands East Indies. ${ }^{40}$ Sidotopo area also built public housing for indigenous employees as many as 300 unit. $^{41}$

Surabaya City Council also participated in the program to promote cheap people housing. Like doing the Housing Exhibition of the people who followed by the people of Surabaya city which will be used as an example or model of public housing projects. There were 31 participants who passed with 131 images received, which includes 12 types of housing. The city council will install a price range of public housing for the indigenous population and Europe is about f 250 until $\mathrm{f} 400 .{ }^{42}$ This is done in connection with the increasingly lack of housing for the people of Surabaya.

In 1925, several societal associations belonging to the Sociaal Technische Vereniging Association held a "Volkshuisvesting Congress" in the city of Semarang. In this congress report produces three things that will be done, namely: 1 . House resident indigenous people; 2. Repairs of slum kampong for the long term; 3. Exhibition of residential housing. As for the slum houses, there are three experts who noted, one of them is a native, namely Abdoelrachman, an Anjunct Inspekteur bij de Afdeeling Bouw en Woning

\footnotetext{
40) Het Nieuws van den dag voor Nederlandsch-Indië, February 24, 1914.

41) Het Nieuws van den dag voor Nederlandsch-Indië, October 15, 1919.

42) Bataviaasch Nieuwsblad, May 30, 1918.
} 
Toezicht from Batavia Township. In the exhibition of houses exhibition, shown example of people's houses with the characteristics of Bandung, Pekalongan, and Semarang style made entirely of bamboo and assembled by H. Maclaine Pont. In addition, also many exhibited photos of Javanese homes in the late as well as some miniature homes. This 1925 Congress was attended by representatives from various regions of Java, both Indonesian and Dutch (government officials or community leaders). Visitors to the congress in 1925 about approximately 100 people, of which more than half are natives. ${ }^{43}$

As a result of the results of the congress of the 1925 people's housing, a population residential census conducted by the Surabaya city government in early 1927 reported that there were 72,311 buildings in Surabaya. Among 22,138 huts, 43,828 permanent residences, and 1,663 vacant residences. In addition there are 103 factories, 681 offices, 1,216 Shops, 1,166 food stalls, 943 warehouses and 573 workshops. ${ }^{44}$ It turns out from the results of the census, housing conditions of the poor city of Surabaya looks quite sad environment. Outbreaks of infectious diseases and cholera are often a scourge for them.

Surabaya City Government then built public housing in Sidodadi and East Ketabang as much as 336 houses for construction workers and the urban poor with an initial cost $f 75,000$, which was submitted to the company's Housing (NV Volkshuisvesting) as executor. ${ }^{45}$ Ngaglik and Tambaksari areas are also places for people's housing development. ${ }^{46}$ This public housing company was formed on January $8,1927 .{ }^{47}$ The construction of public housing is directly supervised by the construction and environment by Ir. Strain from Surabaya City Health Department. ${ }^{48}$ The housing construction is planned to be completed by January 1, 1930. ${ }^{49}$ There are approximately 93 houses built with a construction cost $\mathrm{f} 73$ 300. The house is used with a lease system. There are 19 homes for rent at the price $f 15$ per month and 74 houses of $f$ 8.30 per month. ${ }^{50}$ The house consists of a front porch with Type EE, which has 2 rooms, a kitchen and a bathroom with WC (water closet). ${ }^{51}$

For the sake of the realization of the people's housing program, the city government of Surabaya is also working on housing development in Donokerto and Sidodadi areas which are still quite wide vacant land and dismissed all assumption that Surabaya city government will sell the land to

43) Soekiman, op.cit., pp. 122-123.

44) Het Volk: Dagblad voor de Arbeiderspartij, December 06, 1928.

45) Bataviaasch Nieuwsblad, August 09, 1927, De Indische Courant, July 24, 1928.

46) Freek Colombijn, op.cit., pp. 442.

47) Verslag der Gemeente Soerabaja over het jaar 1927 (Soerabaja: Drukkerij E. Fuhri \& Co), pp. 124.

48) Soerabaijasch Handelsblad, November 21, 1929.

49) Soerabaijasch Handelsblad, June 29, 1929.

50) Het Nieuws van den dag voor Nederlandsch-Indie, June 16, 1932.

51) De Indische Courant, March 21, 1930. 
private parties. Surabaya city government keeps working with private parties only in the matter of building construction which is assisted by public housing company as housing provider institution. ${ }^{52}$ Public housing companies are building housing again in Sidodadi called "Sidodadi III Project" and "Simolawang Project.". 53

Table 2.

Construction of

Public Housing in

Surabaya City by NV.

Volkshuisvesting 1925-

1930.

Source: De Indische Courant,

July 31, 1930.

\begin{tabular}{|c|c|c|}
\hline Unit Houses & Housing Area & Cost (f) \\
\hline 72 & Ketabang Timur I & 225.000 \\
\hline 350 & Ketabang Timur II & 327.000 \\
\hline 61 & Ketabang Timur & 324.000 \\
\hline 316 & Sidodadi & 100.000 \\
\hline 26 & Pasar Keling & 153000 \\
\hline 94 & Oendaan II & 530.000 \\
\hline 184 & Simolawang & 807.000 \\
\hline 68 & Sidodadi II & 85.000 \\
\hline Total: 1.171 units & & Total: 2.551.000 \\
\hline
\end{tabular}

The Surabaya government will build public housing as many as 20,000 units. In accordance with the agreement with members of Surabaya City Council. And aims to reduce the size of slum dwellings in the city of Surabaya, amounting to about 1,000 units. ${ }^{54}$ So the urban poor living in the shantytowns can live in more decent homes. Nevertheless, the fulfillment of public housing is not worth the planning.

Public housing programs in general are not running maximally at the national level. As Freek Colombijn and James Cobban observe, in his study of the colonial people's housing, concluded that the Colonial Government in the Dutch East Indies could not carry out its program maximally through its Colonial Government, N.V. Volkshouisvesting. This is because the built housing there is quite expensive and too few and not suitable for home design for low-income residents. So that ultimately it is taken by the upper middle class and urban areas and does not reach the poor indigenous people. ${ }^{55}$

These advances can not stem the growing number of unsanitary, slum and wild settlements, meaning that the policy of kampong improvement and community housing has not been maximized to prevent the process of deteriorating the housing environment of the kampong, even the more densely populated, Resulting from the large number of people coming to town to stay and find work. As in the proof of the report of the kampong

52) Soerabaijasch Handelsblad, February 04, 1935.

53) Soerabaijasch Handelsblad, November 06, 1932, De Indische Courant, March 21, 1930.

54) Het Nieuws van den dag voor Nederlandsch-Indië, February 21, 1930.

55) Kotapraja, No. 7, Oktober 10, 1951, pp. 4-5 dan James L. Cobban. 1993. Public Housing in Colonial Indonesia 1900-1940 (Inggris: Cambridge University Press), pp. 895. 
improvement commission (1939), as follows: “... in large cities, the number of poor residents is increasingly far behind. This means that in some kampong the number of occupants per house continues to increase, by leasing some of its rooms and buildings to others ... ".56

\section{Conclusion}

The ever-increasing population growth in Surabaya affects the kampong situation. Those who are mostly lowly employees or city workers are not sufficiently capable of improving their unhealthy environment. Not surprisingly since the early 20th century began to emerge the epidemic of the spread of infectious diseases and has caused casualties. So it is necessary for the role of government in overcoming it.

Based on the above explanation, in addition to the role of government, there is also the role or participation of community leaders who are interested in the problems of the kampong and public housing such as Tillema, Thomas Karsten, Von Vaber, Westerveld and dr Soetomo. It can be argued that without the encouragement of groups concerned with the condition of indigenous peoples, the policy of kampong improvement and the provision of public housing will not be realized. As with the start of the 1925, Public Housing Congress in Semarang, that encouraged the establishment of N.V. Volkshuisvesting as an institution conducting the development of public housing in the city of Surabaya and the establishment of a water pump as one part in improving the kampong in the city of Surabaya.

As a result the government conducted kampong improvements in the areas of Krembangan and Kapasan and built public housing in East Ketabang and Sidodadi. So it can be concluded that the concept of improving the kampong and people's housing already existed in the colonial period in the city of Surabaya and without any significant obstacles.

\section{References}

\section{Archives}

Arsip Nasional Republik Indonesia, BB, no. 1696.

Verslag der Gemeente Soerabaja over het jaar 1927. Soerabaja: Drukkerij E. Fuhri $\&$ Co.

Verslag der Gemeente Soerabaja over 1918. Soerabaja: J.M.C.H.S Nijland.

\section{Newspapers}

Arnhemsche Courant, 04 August 1916.

Provinciale Geldersche en Nijmeegsche Courant, 28 October 1920.

De Indische Courant, 26 February 1926.

De Indische Courant, 23 November 1927.

56) Amir Karamoy, op. cit., pp. 38. 
De Indische Courant, 25 April 1928.

De Indische Courant, 24 July 1928.

De Indische Courant, 21 March 1930.

De Indische Courant, 09 July 1930.

De Indische Courant, 15 February 1934.

De Indische Courant, 24 July 1937.

Het Nieuws van den dag voor Nederlandsch-Indië, 24 February 1914.

Het Nieuws van den dag voor Nederlandsch-Indië, 15 October 1919.

Het Nieuws van den dag voor Nederlandsch-Indië, 21 February 1930.

Het Nieuws van den dag voor Nederlandsch-Indie, 16 June 1932.

Het Nieuws van den dag voor Nederlandsch-Indië, 07 Jully 1936.

Het Nieuws van den dag voor Nederlandsch-Indië, 31 May 1938.

Bataviaasch Nieuwsblad, 30 May 1918.

Bataviaasch Nieuwsblad, 09 August 1927.

Het Volk: Dagblad voor de Arbeiderspartij, 06 December 1928.

Limburgsch Dagblad, 01 March 1929.

Soerabaijasch Handelsblad, 29 June 1929.

Soerabaijasch Handelsblad, 21 November 1929.

Soerabaijasch Handelsblad, 25 February 1931.

Soerabaijasch Handelsblad, 6 November 1932.

Soerabaijasch Handelsblad, 04 February 1935.

Soerabaijasch Handelsblad, 12 July 1939.

Kotapraja, No. 7 Tahun ke-II, Tanggal 10 Oktober 1951.

Prisma No. 6, tahun 1984/XIII

\section{Books}

Abidin Kusno (2012). Zaman Baru Generasi Modernis: Sebuah Catatan Arsitektur. Yogyakarta: Ombak.

Adrian Vickers (2005). Sejarah Indonesia Modern. Yogyakarta: Insan Madani.

Andjarwati Noordjanah (2004). Komunitas Tionghoa di Surabaya (1900-1946). Semarang: Masyarakat Indonesia Sadar Sejarah.

Barlan Setiadijaya (1992). 10 November 1945 Gelora Kepahlawan Indonesia. Jakarta: Yayasan 10 November 1945.

Djoko Soekiman (2011). Kebudayaan Indis: Dari Zaman Kompeni sampai Revolusi. Jakarta: Komunitas Bambu.

Dukut Imam Widodo (2004). Soerabaia Tempo Doeloe. Buku 2. Surabaya: Dinas Pariwisata dan Kebudayaan Surabaya.

Freek Colombijn, dkk. (2015). Kota Lama, Kota Baru: Sejarah Kota-Kota di Indonesia Sebelum dan Setelah Kemerdekaan. Yogyakarta: Ombak.

Handinoto (2010). Arsitektur dan Kota-kota di Jawa pada Masa Kolonial. Yogyakarta: Graha Ilmu.

Handinoto (1996). Perkembangan Kota dan Arsitektur Kolonial Belanda di Surabaya (1870-1940). Yogyakarta: Universitas Kristen Petra Surabaya dan Penerbit Andi.

Handinoto dan Paulus H. Soehargo (1996). Perkembangan Kota Dan Arsitektur Kolonial Belanda Di Malang. Yogyakarta: Andi Offset.

James L. Cobban (1993). Public Housing in Colonial Indonesia 1900-1940. Inggris: Cambridge University Press. 
Johny A. Khusyairi dan La Ode Rabani (2011). Kampung Perkotaan Indonesia: Kajian Historis-Antropologis atas Kesenjangan Sosial dan Ruang Kota. Yogyakarta: New Elmatera.

M.C. Ricklefs (2007). Sejarah Indonesia Modern 1200 - 2004. Jakarta: PT. Serambi Ilmu Semesta.

Nasution (2006). Ekonomi Surabaya pada Masa Kolonial 1830-1930. Surabaya: Intelektual.

Olivier Johannes Raap (2015). Kota di Djawa Tempo Doeloe. Jakarta: Kepustakaan Populer Gramedia.

Oliver Johannes Raap (2013). Pekerdja di Djawa Tempo Doeloe. Yogyakarta: Galang Pustaka.

Peter J.M. Nas (2007). Kota-Kota Indonesia Bunga Rampai. Yogyakarta: UGM Press.

Peter J.M. Nas dan Martien De Vletter (2009). Masa Lalu dalam Masa Kini:Arsitektur Indonesia. Jakarta: PT. Gramedia Pustaka Utama.

Pieter Creutzberg dan J.T.M. van Laanen (1987). Sejarah Statistik Ekonomi Indonesia. Jakarta: Yayasan Obor Indonesia.

Rudolf Mrazek (2006). Engineers of Happy Land: Perkembangan Teknologi dan Nasionalisme di Sebuah Koloni. Jakarta: Yayasan Obor Indonesia.

Sartono Kartodirdjo (1993). Pengantar Sejarah Indonesia Baru: Sejarah Pergerakan Nasional, dari Kolonialisme sampai Nasionalisme, Jilid 2. Jakarta: PT Gramedia.

Sri Margana dan M. Nursam (2010). Kota-Kota di Jawa: Identitas, Gaya Hidup dan Permasalahan Sosial. Yogyakarta: Ombak.

Taufik Abdullah dan Sukri Abdurrachman (ed) (2011). Indonesia Across Orders: Arus Bawah Sejarah Bangsa (1930-1960). Jakarta: LIPI Press.

Tillema (1915-1922). “Kromoblanda”: Over't Vraagstuk van 'het Wonen' in Kromo's Groote Land, deel. 1. s-Gravenhage: Uden Masman (etc).

Von Faber, G.H. (1936). Nieuw Soerabaia: De Geschiedenis van Indie's Voornaamste Koopstad in de Eerste Kwarteeuw Sedert Hare Instelling 1906-1931. Soerabaia: N.V. Boekhandel en Drukkerij.

William H Frederick (1989). Pandangan dan Gejolak: Masyarakat Kota dan Lahirnya Revolusi Indonesia (Surabaya 1926-1946). Jakarta: Gramedia. 